\title{
FOLIAR APPLICATION OF SILICON ON YIELD COMPONENTS OF WHEAT CROP $^{1}$
}

\author{
THOMAS NEWTON MARTIN ${ }^{2 *}$, UBIRAJARA RUSSI NUNES ${ }^{2}$, JESSICA DEOLINDA LEIVAS STECCA $^{2}$, \\ DIÓGENES BARELLA PAHINS ${ }^{2}$
}

\begin{abstract}
Wheat is a major winter crop in southern Brazil. To maximize its productivity, there should be no biotic or abiotic restrictions that can affect the yield components. Thus, the objective was to evaluate the changes caused in the wheat crop yield components by silicon foliar application. The experiment was conducted in two growing seasons. In the first year, five wheat cultivars (Quartzo, Campo Real, Onix and Fundacep Lineage) were assessed and in the second year four were assessed (Mirante, Campo Real, Horizonte and Quartzo). In both years the crops were subjected to three doses of silicon $\left(0,3\right.$ and $6 \mathrm{~L}$ of silicon ha $\left.{ }^{-1}\right)$. The silicon was applied during the tillering, booting and anthesis stages. The yield components assessed were the number of plants, number of ears, number of fertile tillers, dry matter per plant, hectoliter weight, number of spikelets, number of grains per spike, weight of hundred grains, grain yield and harvest index. Most yield components did not respond to the silicon foliar application. The harvest index (first year) and the number of tillers (second year) however presented a quadratic relationship with the supply of silicon. The remaining differences were attributed to variations among the wheat cultivars.
\end{abstract}

Keywords: Triticum aestivum L.. Cultivars. Nutritional management.

\section{APLICAÇÃO FOLIAR DE SILÍCIO NOS COMPONENTES DO RENDIMENTO DO TRIGO}

RESUMO - O trigo é uma das principais culturas de inverno na região Sul do Brasil e para que a sua produtividade seja maximizada necessita que não haja restrições bióticas ou abióticas que possam afetar seus componentes de rendimento. Dessa forma, objetivou-se com esse trabalho avaliar as alterações provocadas nos componentes do rendimento da cultura de trigo pela aplicação de silício via foliar. O experimento foi conduzido em dois anos agrícolas. No primeiro ano foram avaliadas cinco cultivares de trigo (Quartzo, Campo Real, Horizonte, Ônix e Linhagem Fundacep), e quatro cultivares no segundo ano (Mirante, Campo Real, Horizonte e Quartzo), em ambos os anos foram submetidas a três doses de silício (0, 3 e 6 L de silício ha $\left.{ }^{-1}\right)$. As aplicações de silício foram realizadas nas fases do afilhamento, alongamento e antese. Os componentes de rendimento avaliados foram o número de plantas, o número de espigas e o número afilhos férteis, matéria seca por planta, massa de hectolítro, número de espiguetas, número de grãos por espiga, massa de cem grãos, produção de grãos e índice de colheita. A maioria dos componentes de rendimento não respondeu a aplicação foliar de silício. Contudo, o índice de colheita (primeiro ano) e o número de afilhos (segundo ano) apresentaram incrementos de suas características com a adição da adubação com silício via foliar. As demais diferenças observadas são atribuídas às variações entre as cultivares de trigo.

Palavras-chave: Triticum aestivum L.. Cultivares. Manejo nutricional.

\footnotetext{
*Corresponding author

${ }^{1}$ Received for publication in 08/07/2015; accepted in 07/18/2016.

Paper extracted from the undergraduate thesis of the fourth author.

${ }^{2}$ Department of Crop Science, Universidade Federal de Santa Maria, Santa Maria, RS, Brazil; martin.ufsm@gmail.com, russinunes@yahoo.com.br, jessica.stecca@yahoo.com.br, dbarella66@hotmail.com.
} 


\section{INTRODUCTION}

The wheat grain is the second most cultivated crop in the world by volume, with production of around 2.7 billion tons (CONAB, 2016). Biotic and abiotic factors affect the yield components of wheat throughout the crop cycle (MA, 2004) and are the result of plant-environment interactions. Balanced nutrition results in increased production potential for wheat plants, thus it is important that the plants grow and develop in the presence of essential mineral elements, which must be readily available to them. In addition to these essential elements, there are other elements that benefit plant nutrition, such as silicon (Si) (TAKAHASHI; MIYAKE, 1977).

Silicon is not considered an essential element to most higher plants (KORNDÖRFER; PEREIRA, 2001), since it does not fit the essentiality criteria. In general, plants are considered good accumulators of silicon, with $>1 \%$ accumulation of this mineral (MA et al., 2001). Therefore, silicon is effective in many species of plants, since it regulates transpiration (MA; TAKAHASHI, 2002), actsas an anti-stress factor, minimizes the harmful effects of extreme climatic factors such as water stress (KARMOLLACHAAB et al., 2013) and reduces the incidences of disease (MA, 2004; SORATTO et al., 2012) and pests, as well as toxicity caused by toxic elements in the soil (TAHIR et al., 2006).

Silicon is the element with the second highest concentration on the coast land, but it is often not readily available for uptake by plants, which primarily absorb this element in mono-silicon acid form $\left(\mathrm{H}_{4} \mathrm{SiO}_{4}\right)$. In wheat, seedlings have been found with silicon deposits in the structural tissues, vascular tissues, storage tissues and the epidermis (LIMA FILHO; TSAI, 2007). According to Casey et al. (2003), wheat plants actively absorb this element.

Higher $\mathrm{Si}$ concentrations are related to disease resistance (Blumeria graminis f. sp trtici) (BÉLANGER; BENHAMOU; MENZIES, 2003). In environments with aluminum toxicity, two maize genotypes were tested, one tolerant and one sensitive to $\mathrm{Al}$. In both, silicon reduced the toxic effect on plant root growth (GIONGO; BOHNEN, 2011).

Applying silicon to wheat increased plant resistance to attack by "greenbug" (Schizaphis graminum) (COSTA; MORAES; COSTA, 2009). It also offered protection from fungal attacks by providing greater resistance for flag leaves against the fungus Bipolaris sorokiniana (DOMICIANO et al., 2010). Other authors have also had positive results applying silicon to several crops, in adverse biotic and abiotic environments (NERI et al., 2009).

Silicon plays an important role in many plant species, in a less aggressive way to the environment. Itis beneficial for agricultural crops grown in stressful environments, such as soils with low water potential or toxic elements and in times of insect attacks and disease. The magnitude of the benefits of
Si and its effect on the conditions of wheat crop yield components in Rio Grande do Sul, Brazil, are unknown. Thus, the aim of this work was to assess the changes in the yield components of wheat crop caused by silicon foliar application.

\section{MATERIAL AND METHODS}

The experiment was carried out in 2011 and 2012 at the Federal University of Santa Maria, $29^{\circ}$ $43^{\prime} 2.81^{\prime \prime} \mathrm{S}, 53^{\circ} 43^{\prime} 58.28^{\prime \prime} \mathrm{W}$ at an altitude of $116 \mathrm{~m}$. The prevailing climate is of humid subtropical type (Cwa) according to Köppen classification. Soil samples were collected at a depth of 0-0.2 redultisol, with the following averages for the first year: $\mathrm{pH}$ in water: 5.0; index: SMP 5.5; Saturation bases and Aluminum: 59.9 and 5.7 (\%); effective CTC: $12.3\left(\mathrm{cmolc} / \mathrm{dm}^{3}\right)$; CTC pH7: $19.3\left(\mathrm{cmolc} / \mathrm{dm}^{3}\right)$; K: 0.225 (cmolc/dm $\left.{ }^{3}\right)$; P-Mehlich: $18.9\left(\mathrm{mg} / \mathrm{dm}^{3}\right)$; S: $16.3\left(\mathrm{mg} / \mathrm{dm}^{3}\right)$; \%MO: $2.8(\mathrm{~m} / \mathrm{v})$; \%Clay: $27.0(\mathrm{~m} / \mathrm{v})$; Ca: $8.3\left(\mathrm{cmolc} / \mathrm{dm}^{3}\right) ; \mathrm{Mg}: 3.0\left(\mathrm{cmolc} / \mathrm{dm}^{3}\right) ; \mathrm{Al}: 0.7$ $\left(\mathrm{cmolc} / \mathrm{dm}^{3}\right) ; \quad \mathrm{H}+\mathrm{Al}: \quad 7.7 \quad\left(\mathrm{cmolc} / \mathrm{dm}^{3}\right) ; \quad \mathrm{Cu}:$ $0.9\left(\mathrm{mg} / \mathrm{dm}^{3}\right) ; \mathrm{Zn}: 1.5\left(\mathrm{mg} / \mathrm{dm}^{3}\right)$; B: $0.6\left(\mathrm{mg} / \mathrm{dm}^{3}\right)$, Si: $6.4 \mathrm{mg} \mathrm{dm}^{-3}$; and texture 3 . For the second year the averages were: $\mathrm{pH}$ in water: 4.8 ; index: SMP 5.2; Saturation bases and Aluminum: 44.0 and $15.0(\%)$ respectively; effective CTC: $10.0\left(\mathrm{cmolc} / \mathrm{dm}^{3}\right)$; CTC pH7: $19.4 \quad\left(\mathrm{cmolc} / \mathrm{dm}^{3}\right) ; \mathrm{K}: 0.153 \quad\left(\mathrm{cmolc} / \mathrm{dm}^{3}\right)$; P-Mehlich: $12.6\left(\mathrm{mg} / \mathrm{dm}^{3}\right)$; \%MO: 2.4 (m/v); \%Clay: $24.0(\mathrm{~m} / \mathrm{v})$; Ca: 5.7 (cmolc/dm $\left.{ }^{3}\right)$; Mg: 2.7 (cmolc/ $\left.\mathrm{dm}^{3}\right)$; Al: $1.5\left(\mathrm{cmolc} / \mathrm{dm}^{3}\right)$; $\mathrm{H}+\mathrm{Al}: 10.9\left(\mathrm{cmolc} / \mathrm{dm}^{3}\right)$; Si: $6.8 \mathrm{mg} \mathrm{dm}^{-3}$ and texture 3 .

The experiment was conducted using a randomized block design with four replications, with the treatments arranged in a factorial (5X3). In the first year, five cultivars were tested (Quartzo, Campo Real, Horizonte, Onix and Fundacep lineage) and three doses of silicon (control without application, three and six $\mathrm{L} \mathrm{ha}^{-1}$ in the form of monosilicon acid). Each plot was $3.5 \mathrm{~m}$ long and $3 \mathrm{~m}$ wide. In the second year, four cultivars were tested (Mirante, Campo Real, Horizonte and Quartzo), subjected to the same doses of $\mathrm{Si}$, with each plot being $4 \mathrm{~m}$ long and $2 \mathrm{~m}$ wide. The distance between the rows of sowing was $0.2 \mathrm{~m}$ in both experiments.

All crop management followed the guide lines of the Comissão Brasileira de Pesquisa de Trigo e Triticale (Brazilian Commission on Wheat and Triticale Research), as described below. The experimental area was managed with Gliphosate herbicide at a dosage of $5.0 \mathrm{~L} \mathrm{ha}^{-1}, 15$ days before sowing. Seeds were treated before sowing with the insecticide IMIDACLOPRID $150 \mathrm{~g} \quad \mathrm{~L}^{-1}$ +THIODICARB $450 \mathrm{~g} \mathrm{~L}^{-1}$ (Cropstar ${ }^{\circledR}$ ), at a dosage of $0.3 \mathrm{~L}$ per $100 \mathrm{~kg}$ of seeds along with TRIAZOL $270 \mathrm{~g} \mathrm{~L}^{-1}\left(\right.$ Baytan $\left.^{\circledR}\right)$.

In the 2011 crop, seeding was done on June 16 , using an average of 410 viable seeds per square meter. For basic fertilization, $300 \mathrm{~kg} \mathrm{ha}^{-1}$ was 
applied, using the commercial formula NPK 5-30-20. In 2012, seeding was done on June 8, an average of 350 viable seeds per square meter. In basic fertilization, $300 \mathrm{~kg} \mathrm{ha}^{-1}$ was applied using the commercial formula NPK 5-20-20.

Weeds were controlled during the experiments with the use of the systemic herbicide IODOSULFURON-METHYL (Hussar ${ }^{\circledR}$ ) at the dose of $0.10 \mathrm{~kg} \mathrm{ha}^{-1}$ in the tillering phase of the wheat crop. Stink bugs and green bugs were controlled with a systemic insecticide IMIDACLOPRID + BETA-CYFLUTHRIN (Connect ${ }^{\circledR}$ ) at a dosage of 0.5 $\mathrm{L} \mathrm{ha}^{-1}$, applied twice (tillering and booting stages). Disease management was done with the fungicide TRIFLOXYSTROBIN + TEBUCONAZOLE (Nativo ${ }^{\circledR}$ ) at a dosage of $0.6 \mathrm{~L} \mathrm{ha}^{-1}$ and $0.4 \mathrm{~L} \mathrm{ha}^{-1}$, applied in the tillering, booting and an thesis stages.

The silicon was applied by coast spraying, totaling three silicon applications during the crop cycle. The first occurred in the tillering stage: stage 3 (tillers formed), the second in the stretch: stage 8 (last leaf emergence) and the third at anthesis: stage 10.1 (silking) of the crop. Crop phenology was based on the Feeks-Large scale.

The crops were harvested when the grains had an average moisture of $16 \%$. In the $2011 \mathrm{crop}$, the harvest was held on November 3, 2011 and in 2012 the crop was harvested on October 25, 2012. The characteristics evaluated were the number of plants (NP), number of fertile tillers (NFT), number of spikes $\left(\mathrm{NS}, \mathrm{m}^{-2}\right)$, dry matter per plant (DMP, g), number of spikelets (NSS), number of grains per

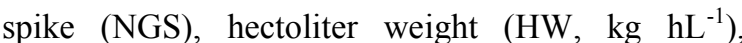
weight of one hundred grains (WHG, g), grain production (GP, $\mathrm{Mg} \mathrm{ha}^{-1}$ ) and harvest index (HI, \%). To assess the weight of hundred grains and the hectoliter weight, rules for seed testing were used (BRASIL, 2009).

The assumptions of the mathematical model (additivity, normality, homogeneity and random error) were tested. Data were subjected to analysis of variance and the interaction was verified between the factors and the application of multiple means comparison test was done (Duncan, 5\% of error probability) and polynomial regression analysis (up to the second degree), using the software Sisvar ${ }^{\mathbb{B}}$ (FERREIRA, 2011).

\section{RESULTS AND DISCUSSION}

The experiment was conducted without pests, diseases or weeds interfering with the experimental results, the result of the applied experimental management. From the analysis of the assumptions of the mathematical model (additivity, normality, homogeneity and random error), it was shown that none of the assumptions were violated for the any of the variables evaluated over both years of the experiment. According to the variance analysis the interaction between the factors (cultivars $\mathrm{x}$ Si doses) was not significant for any of the traits evaluated in two harvests (Table 1).

Table 1. Analysis of variance for the characteristics assessed: number of plants (NP, $\left.\mathrm{m}^{-2}\right)$, number of spikes (NS, $\left.\mathrm{m}^{-2}\right)$, number of fertile tillers (NFT), dry matter per plant (DMP, g), hectoliter weight (HW, $\mathrm{kg} \mathrm{hL}^{-1}$ ), number of spikelets (NSS), number of grains per spike (NGS), plant height $(\mathrm{PH}, \mathrm{cm})$, weight of one hundred grains (WHG, g), grain production (GP, Mg ha ${ }^{-1}$ ) and harvest index (HI, \%) for the 2011 and 2012 harvests.

\begin{tabular}{cccccc}
\hline 2011 & NP & NS & NFT & DMP & WH \\
\hline Quartzo & $250.83 \mathrm{ab} *$ & 457.5 & $1.83 \mathrm{ab}$ & $1.89 \mathrm{ab}$ & $77.08 \mathrm{c}$ \\
Onix & $248.33 \mathrm{ab}$ & 442.92 & $1.79 \mathrm{ab}$ & $1.72 \mathrm{bc}$ & $78.70 \mathrm{ab}$ \\
Fundacep Lineage & $261.25 \mathrm{a}$ & 442.08 & $1.72 \mathrm{~b}$ & $1.95 \mathrm{a}$ & $78.32 \mathrm{ab}$ \\
Campo Real & $269.17 \mathrm{a}$ & 474.17 & $1.78 \mathrm{ab}$ & $1.56 \mathrm{c}$ & $77.83 \mathrm{bc}$ \\
Horizonte & $233.75 \mathrm{~b}$ & 459.17 & $1.97 \mathrm{a}$ & $1.76 \mathrm{abc}$ & $79.05 \mathrm{a}$ \\
\hline Average & 252.67 & 455.17 & 1.82 & 1.78 & 78.2 \\
CV(\%) & 10.11 & 8.63 & 13.2 & 13.72 & 1.69 \\
\hline NSS & 13.91 & NGS & MHG & PG & HI \\
\hline Quartzo & 13.63 & $30.13 \mathrm{ab}$ & $3.66 \mathrm{a}$ & $3.310 \mathrm{a}$ & $0.42 \mathrm{ab}$ \\
Onix & 13.43 & $31.16 \mathrm{a}$ & $3.21 \mathrm{~b}$ & $2.834 \mathrm{~b}$ & $0.40 \mathrm{~b}$ \\
Fundacep Lineage & 13.23 & $29.37 \mathrm{ab}$ & $2.87 \mathrm{c}$ & $3.061 \mathrm{ab}$ & $0.38 \mathrm{~b}$ \\
Campo Real & 13 & $26.67 \mathrm{~b}$ & $3.20 \mathrm{~b}$ & $3.387 \mathrm{a}$ & $0.49 \mathrm{a}$ \\
Horizonte & 13.44 & 29.97 & 3.34 & $3.219 \mathrm{a}$ & $0.42 \mathrm{ab}$ \\
\hline Average & 7.01 & 14.93 & 5.74 & 3.16 & 0.42 \\
CV(\%) & N & 13.63 & 22.96 \\
\hline
\end{tabular}

*means with different letters differ at $5 \%$ of probability by Duncan's test. Percent coefficient of variation (CV\%). 
T. N. MARTIN et al.

Table 1. Continuation

\begin{tabular}{cccccc}
\hline 2012 & NP & NS & NFT & DMP & WH \\
\hline Quartzo & $261.67 \mathrm{a}$ & 291.25 & $274.58 \mathrm{a}$ & $2.20 \mathrm{~b}$ & $68.97 \mathrm{a}$ \\
Mirante & $167.91 \mathrm{c}$ & 366.25 & $125.41 \mathrm{c}$ & $2.56 \mathrm{a}$ & $65.01 \mathrm{~b}$ \\
Horizonte & $201.36 \mathrm{~b}$ & 370.9 & $154.54 \mathrm{cb}$ & $2.45 \mathrm{a}$ & $64.18 \mathrm{~b}$ \\
Campo Real & $222.08 \mathrm{~b}$ & 338.33 & $197.08 \mathrm{~b}$ & $1.78 \mathrm{c}$ & $66.48 \mathrm{~b}$ \\
\hline Average & 213.51 & 341.06 & 188.61 & 2.24 & 66.16 \\
CV(\%) & 17.07 & 28.64 & 27.64 & 10.53 & 2.4 \\
\hline Quartzo & NSS & HP & MHG & PG & HI \\
Mirante & $70.41 \mathrm{~b}$ & $73.56 \mathrm{c}$ & $2.65 \mathrm{c}$ & $3120.32 \mathrm{c}$ & $0.35 \mathrm{c}$ \\
Horizonte & $69.04 \mathrm{~b}$ & $84.18 \mathrm{a}$ & $3.45 \mathrm{a}$ & $3544.20 \mathrm{~b}$ & $0.39 \mathrm{ab}$ \\
Campo Real & $75.50 \mathrm{a}$ & $84.39 \mathrm{a}$ & $3.08 \mathrm{~b}$ & $4111.09 \mathrm{a}$ & $0.39 \mathrm{a}$ \\
\hline Average & $68.37 \mathrm{~b}$ & $80.60 \mathrm{~b}$ & $2.61 \mathrm{c}$ & $3532.18 \mathrm{~b}$ & $0.36 \mathrm{bc}$ \\
\hline CV(\%) & 70.73 & 80.6 & 2.95 & 3576.95 & 12.27 \\
\hline
\end{tabular}

*means with different letters differ at $5 \%$ of probability by Duncan's test. Percent coefficient of variation (CV\%).

Through the analysis of variance it was observed that the interaction between the factors (crops $\mathrm{x}$ silicon doses) did not present significance for any of the characteristics evaluated in either harvest. With regard to the interaction among the factors (crops $\mathrm{x}$ Si doses), it was shown that by using different crops, with different cycles, origins and technological requirements, production and years of evaluation, a wide range of conditions were provided that enabled the identification of any effect of foliar silicon application, if one exists. Si plays an important role in plant-environment interactions, since it helps plants withstand adverse biological, soil and climate conditions (LIMA FILHO; TSAI, 2007). Wang and Liang (2001) report that under specific conditions silicic fertilization has increased crop productivity in China. The genotype used, as well as the lack of $\mathrm{Si}$, should be more likely to provide positive feedback to the crop yield, however. That certainly occurs, because in addition to variations in the absorptive capacity of the different cultivars, there are also variations in the silicon content of plants at different development stages. Wheat plants are more dependent on $\mathrm{Si}$ in the tillering phase (AHMAD; HADDAD, 2011), and Si accumulation is greatest in the upper leaves, such as the flag leaf (SORATTO et al., 2012; ANDRADE; ANDRADE; MIGLIORANZA, 2012). From the unfolding of the interaction for all factors however, it was not possible to detect changes in the performance of cultivars from different applications of silicon doses. Thus, it is understood that the assessed characteristics of different cultivars, across different years and study conditions, do not change because of the application of $\mathrm{Si}$.

It is noted that for the 2011 harvest, the cultivars differed from one another in terms of intrinsic characteristics, namely the averages of NP, NPT, DMP, WH, NGS, MHG, GP and HI. Regarding NS and NSS, the wheat cultivars Quartzo, Onix, Fundacep Lineage and Horizonte did not differ significantly. For the 2012 harvest, the cultivars differed in NP, NFT, DMP, MHG, GP, HI, which was similar to the results of the previous crop, with differences also noted for HP. The cultivars Mirante and Horizonte did not differ significantly by the characteristics NS, DMP, HI and HP. The cultivars Horizonte and Mirante, which had greater plant height, are probably the most susceptible to lodging. Therefore, when silicon is deposited as anamorphic silica on cell walls it can act to help maintain the mechanical properties of the cell walls, such as rigidity and elasticity. Regarding PG, it is noted that the cultivar Horizonte differed significantly from the other cultivars (Table 1).

NP presented significant differences among genotypes in both years. Although seeding was done with 410 suitable seeds $\mathrm{m}^{-2}$ and 350 suitable seeds $\mathrm{m}^{-2}$, NP was still less than desired. According to some authors (EMBRAPA, 2011) the NP must be above 330 plants per $\mathrm{m}^{-2}$. Despite this, the different cultivars had different NPF emission abilities (that produce spikes), which homogenized the NS per area and NSS. The ability of the plants to emit fertile tillers, and therefore produce spikes, allows for the homogenization of treatments by regulating the cultivars in adjustment of the stand for the ability to support the environment in which the plant is found (VALÉRIO et al., 2013). In addition, the number of plants is a function of the number of viable seeds sown per square meter and is not influenced by foliar applications of $\mathrm{Si}$, since treatments were applied 
from tillering in both years.

There is a trend in reducing the number of tillers per plant, hence the NPF (COMMON; KLINCK, 1981). To make this possible however one should explore genetic gains in wheat, with improvements in the photosynthetic process exploiting the natural variation of the Rubiscocatalytic rate or adopting the $\mathrm{C}_{4}$ metabolism, which would increase productivity by at least $50 \%$ (REYNOLDS et al., 2009). Tillering is a key event in wheat crops that fail to sow, heterogeneous climate conditions (frost and heat strokes) among others, since they are able to regulate the number of spikes per hectare (VALÉRIO et al., 2009).

Among the drawbacks however it is noted that the wheat plants are at different stages of development, which can be detrimental to the application of cultural practices, such as applications of fertilizer and fungicide (particularly for FHB).

Regarding DMP, plants have different capacities of dry matter accumulation and this feature is mainly genetic and linked to other aspects of plant morphology, such as height and partitioning of the plant constituents, in addition to the physiological aspects such as the accumulation of carbohydrates for grain formation (SLEEPER; POELMAN, 2006). According to Merah, Monneveux and Deléens (2001), from the carbon isotope discrimination an indirect selection that promotes transpiration efficiency and wheat grain yield can be achieved.

Hectoliter weight is a constituent that measures the quality of the wheat produced and therefore the extraction capacity of the wheat flour. In Brazil wheat is classified into types, with the first type being classified according to hectoliter weight greater than 78 (BRASIL, 2001). In this case, only the genotypes Onyx, the Fundacep lineage and Horizon harvested in 2011 would be classified in this class, with the rest in lower classes. This classification would alter the commercial value paid to farmers. Thus, the choice of genotype should be adjusted to obtain better yields with superior qualities.

For the silicon levels, for the year 2011 only for the harvest index characteristic (HI, \%) there was significance $(\mathrm{p}<0.05)$, showing a quadratic response for the harvest index (Figure 1a). The harvest index is determined by the ratio of plant economic production to organic production. The total biological production, derived from photosynthesis, includes leaves, roots, stems and spikes, but for agriculture the production of biomass is important only from an economic standpoint, i.e., grain yield. Authors such as Lima Filho and Tsai (2007) also observed increases in HI for the wheat crop when considering hydroponic cultivation in vermivulite with an initial $\mathrm{pH}$ adjusted to 6.0 and constant aeration, in a greenhouse. This increase ranged from $45.2 \%$ to $49.6 \%$ ( $\mathrm{Br} 18), 25.7 \%$ to $33.9 \%(\mathrm{Br} 40)$ and of $37.7 \%$ to $47.4 \%$ (IPR 85 ). In both studies the extension of the HI by the $\mathrm{Si}$ application resulted from higher remobilization and retention of photosynthates in the grains. There is a tendency for larger $\mathrm{Si}$ applications providing a change in the source ratio and drain, allocating more carbohydrates for grain formation relative to the total dry matter. This however does not translate into grain yield.

In the second year (2012), there only NFT was statistically significant (Figure 1b), with maximum efficiency when $3.22 \mathrm{~L}$ of $\mathrm{Si} \mathrm{ha}^{-1}$ were applied. This fact is important because tillering may cause an increase in the number of spikes, filling the empty spaces in the field as well as indicating that the plant is in good growing conditions (ZAGONEL et al., 2002). That interference has not been verified in this study, however.

Considering the characteristics assessed over two years it is important to discuss the location of the experiment, the soil, which have levels of silicon that meet the needs of the plants. In general, the soils have between 14 and $20 \mathrm{mg}$ of $\mathrm{Si} \mathrm{L}^{-1}$ and these quantities are insufficient to positively interact with plant development. Furthermore, there were no water deficiencies that could allow better performance of $\mathrm{Si}$, as shown by Karmollachaab et al. (2013), who found that applying $\mathrm{Si}$ in water stress conditions reduces the abiotic effect on the grains yield. For the state of Rio Grande do Sul and Santa Maria in particular, there is a better distribution of rainfall during June and July, which becomes more favorable for the non-occurrence of drought stress (SILVA et al., 2007). This is associated with the low temperatures and rates of evaporation and transpiration, which allow for a greater accumulation of water in the soil profile, thus resulting in a lower frequency of abiotic stresses in the critical stages of the grain yield definition The months of June and July however are times of low solar radiation, low temperatures and high relative humidity. These conditions create an environment conducive to fungal diseases. Culture management by means of de fungicides was done preventively however, which may have reduced the possibility of the Si treatment to activate the protection systems of the plant, as noted by Rémus-Borel et al. (2005). In an experiment conducted in tropical conditions with temperatures higher than those of the present experiment, there was no statistical difference for grain yield (SORATTO et al., 2012), however, these authors worked with the Si available in another form for the plants. Due to the more stressful conditions of the tropical environment, however, the silicon may have enabled better control of transpiration relative to the production obtained in the present study. 

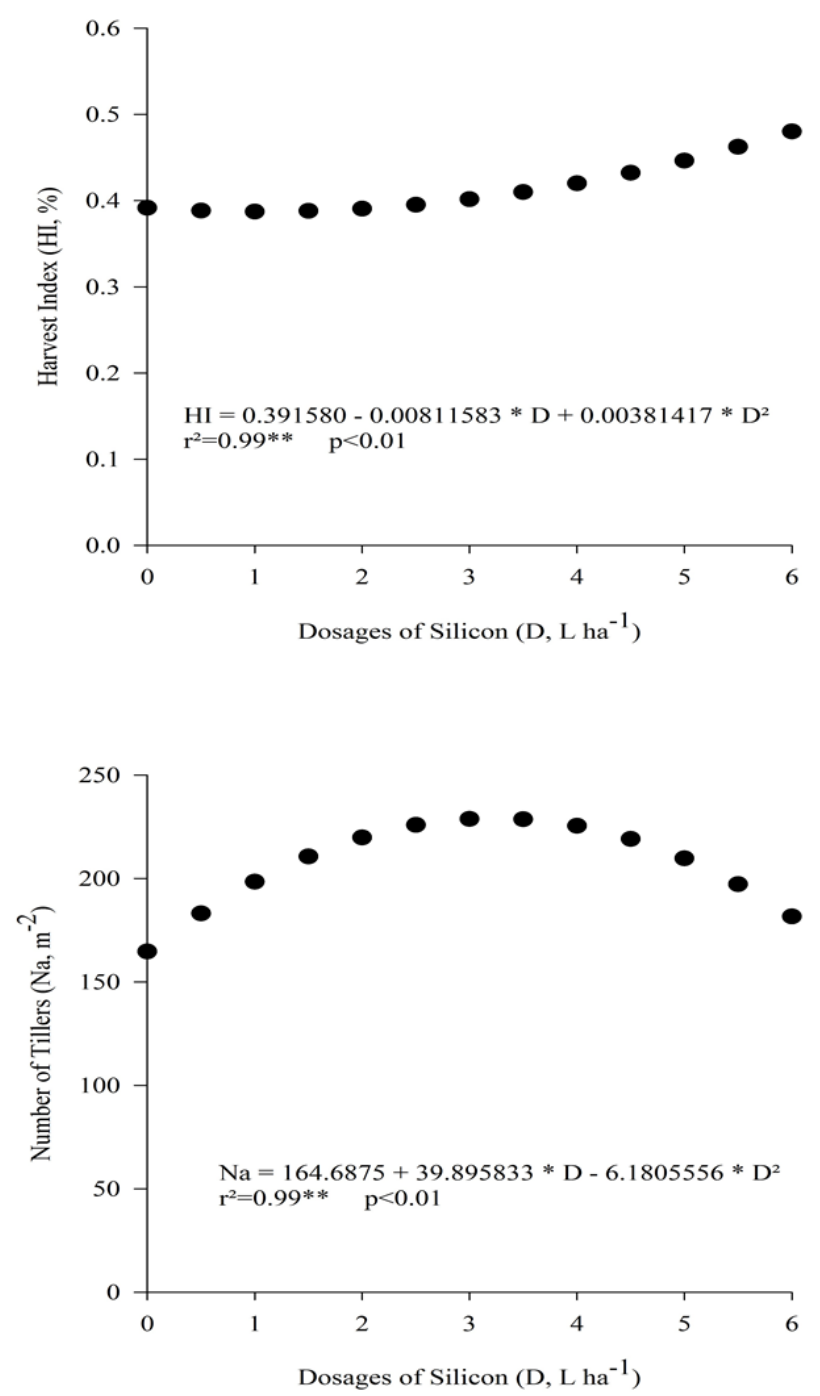

Figure 1. Harvest index for the first year (HI, \%) (a) and number of tillers $\left(\mathrm{Na}, \mathrm{m}^{-2}\right)$ from different doses of silicon (L/ha) in the second year $(b)$.

In research on sugarcane and rice crops, increases were observed in the yield components. The authors reported the benefits of added silicon compensating for losses caused by stress factors, such as the low silicon content of the soil and disease incidence (DATNOFF et al., 2001). Supplementation of $\mathrm{Si}$ under hydroponic conditions positively changed the growth and the yield of wheat and white oat (LIMA FILHO; TSAI, 2007).

Tahir et al. (2006) studied the effects of silicon in saline environments and obtained positive results with increases in plant dry matter and grain yield in two wheat genotypes (one tolerant and the other resilient to $\mathrm{NaCl}$ ). These results demonstrate the efficiency of silicon under stressful environments. In conducting this experiment in the years 2011 and 2012 however, wheat crop development was helped by the weather, with good rainfall averages distributed throughout the crop cycle, along with a good availability of solar radiation that made good wheat crop development possible. Gong et al. (2005) showed that under stress conditions, silicon has a more effective participation in the metabolic and physiological activities of wheat plants when they are under water stress. In addition, plants in this condition have an increased antioxidant defense capacity, oxidative relief functional molecules and maintenance of many physiological processes such as photosynthesis under water stress (AZCÓN et al., 2009). This data is important because of the evaluation of the silicon performance in the wheat crop, because the benefits of silicon were not expressed since the levels of disease, pests, weedy plants, water stress and soil toxicity were insignificant in this work.

There were no stress situations on a critical level for the wheat plants where the silicon could act significantly, as it responds well in situations where there is negative pressure relative to the biotic and abiotic environment. Under these conditions, the benefits of silicon were not observed in the yield components, NP, NS, NPF, DMP, WH, NSS, NGS, MHG, GP. These results differed from those reported in the literature (WANG; LIANG, 2001), 
which indicated that under production conditions in China there was an increase in the yield components of the wheat and corn crops. Thus, conditions should be sought where the crop is subjected to different types of stress in order to produce better results in terms of yield components by using $\mathrm{Si}$.

\section{CONCLUSIONS}

Foliar applications of silicon in wheat cultivars did not affect most crop yield components, but the harvest index and number of tillers were increased by the silicon supply in the 2011 and 2012 harvests.

\section{REFERENCES}

AHMAD, S. T.; HADDAD, R. Study of Silicon Effects on Antioxidant Enzyme Activities and Osmotic Adjustment of Wheat under Drought Stress. Czech Journal of Genetics Plant Breeding, Praha, v. 47, n. 1, p. 17-27, 2011.

ANDRADE, F. A.; ANDRADE, C. G. T. J.; MIGLIORANZA, E. Detecção de sílica em folha bandeira de trigo. Semina: Ciências Agrárias, Londrina,v. 33, n. 1, p. 2555-2562, 2012.

AZCÓN, R. et al. Antioxidant activities and metal acquisition in mycorrhizal plants growing in a heavy metal multicontaminated soil amended with treated lignocellulosica growaste. Applied Soil Ecology, Amsterdam, v.41, n. 2, p. 168-177, 2009.

BÉLANGER, R. R.; BENHAMOU, N.; MENZIES, J. G. Cytological evidence of an active role of silicon in wheat resistance to powdery mildew (Blumeriagraminis f. sptritici). Phytopathology, Campinas, v. 93, n. 4, p. 402-412, 2003.

BRASIL. Ministério da Agricultura, Pecuária e Abastecimento. Instrução Normativa SARC $\mathrm{n}^{0} 7$, de 15 de agosto de 2001. Aprova o regulamento técnico de identidade e qualidade do trigo. Diário Oficial da República Federativa do Brasil, Brasília, 21 de agosto de 2001.

BRASIL. Ministério da Agricultura, Pecuária e Abastecimento. Regras para análise de sementes. Ministério da Agricultura, Pecuária e Abastecimento. Secretaria de Defesa Agropecuária. Brasília, DF: Mapa/ACS, 2009. 395 p.

CASEY, W. H. et al. Aqueous silicate complexes in wheat, Triticum aestivum L. Plant Cell Environment, Oxford, v. 27, n. 1, p. 51-54, 2003.
COMMON, J. C.; KLINCK, H. R. Sequence and synchrony of culm development: implications in breeding for limited tillering barleys. In: INTERNATIONAL BARLEY GENETICS SYMPOSIUM, 4., 1981, Edinburg, Scotland. Proceedings, p. 533-536, 1981.

COMPANHIA NACIONAL

DE ABASTECIMENTO - CONAB. Acompanhamento de safra brasileira: grãos, décimo levantamento, julho 2016. Brasília, 2016. Disponível em: <http:// www.conab.gov.br >. Acesso em: 09 jul. 2016.

COSTA, R. R.; MORAES, J. C.; COSTA, R. R. Interação silício-imida croprid no comportamento biológico e alimentar de Schizaphis graminum (Rond.) (Hemiptera: Aphididae) em plantas de trigo. Ciência e Agrotecnologia, Lavras, v. 33, n. 2, p. 455-460, 2009.

DATNOFF, L. E.; SNYDER, G. H.; KORNDÖRFER, G. H. Silicon in Agriculture: studies in plant science. 1. ed. Amsterdam: Elsevier Science, 2001. 403p.

DOMICIANO, G. P. et al. Silício no progresso da mancha marrom na folha bandeira do trigo. Tropical Plant Pathology, Viçosa, v. 35, n. 3, p. 86-189, 2010 .

EMPRESA BRASILEIRA DE PESQUISA AGROPECUÁRIA - EMBRAPA. Informações Técnicas para Trigo e Triticale - Safra 2012: V Reunião da Comissão Brasileira de Trigo e Triticale-Dourados-MS. Embrapa Agropecuária Oeste, 2011. 204p. (Sistema de produção, 9).

FERREIRA, D. F. Sisvar: a computer statistical analysis system. Ciência e Agrotecnologia, Lavras, v. 35, n. 6, p. 1039-1042, 2011.

GIONGO, V.; BOHNEN H. Relation between aluminum and silicon in maize genotypes resistant and sensitive at aluminum toxicity. Bioscience Journal, Uberlândia, v. 27, n. 3, p. 348-356, 2011.

GONG, H. et al. Silicon alleviates oxidative damage of wheat plants in pots under drought. Plant Science, Saint Louis, v. 169, n. 13-14, p. 313-321, 2005.

KARMOLLACHAAB, A. et al. Effect of Silicon application on physiological characteristics and grain yield of wheat under drought stress condition. International journal of Agronomy and Plant Production, London, v. 4, n. 1, p. 30-37, 2013.

KORNDÖRFER, G. H.; PEREIRA, H. S. Papel do silício na citricultura. Revista Citricultura Atual, Cordeirópolis, v. 25, n. 25, p. 16-18, 2001. 
LIMA FILHO, O. F.; TSAI, S. M. Crescimento e produção do trigo e da aveia branca suplementados com silício. Dourados: Embrapa Agropecuária Oeste, 2007. 34 p. (Boletim de Pesquisa e Desenvolvimento, 41).

MA, J. F.; MIYAKE, Y.; TAKAHASHI, E. Silicon as a beneficial element for crop plant. In: DATNOFF, L. E.; SNYDER, G. H; KORNDÖRFER, G. H. Silicon in agriculture: studies in plant science. 1. ed. Amsterdam: Elsevier Science, 2001. p. 17-34.

MA, J. F.; TAKAHASHI, E. Soil, Fertilizer, and Plant Silicon Research in Japan. 1. ed. Amsterdam: Elsevier Science, 2002. 294 p.

MA, J. F. Role of silicon in enhancing the resistance of plants to biotic and abiotic stresses. Soil Science \& Plant Nutrition, Tokio, v. 50, n. 1, p. 11-18, 2004.

MERAH, O.; MONNEVEUX, P.; DELE'ENS, E. Relationships between flag leaf carbon isotope discrimination and several morpho-physiological traits in durum wheat genotypes under Mediterranean conditions Othmane. Environmental and Experimental Botany, New York, v. 45, n. 1, p. 63-71, 2001.

NERI, D. K. P. et al. Influência do silício na suscetibilidade de Spodoptera frugiperda (J. E. Smith) (Lepidoptera: Noctuidae) ao inseticida lufenuron e no desenvolvimento de plantas de milho. Ciência Rural, Santa Maria, v. 39, n. 6, p. 1633-1638, 2009.

RÉMUS-BOREL, W.; MENZIES, J. G.; BÉLANGER, R. R. Silicon induces antifungal compounds in powdery mildew-infected wheat. Physiological and Molecular Plant Pathology, London, v. 66, n. 3, p. 108-115, 2005.

REYNOLDS, M. P. et al. Raising yield potential in wheat. Journal of Experimental Botany, Oxford, v. 60, n. 7, p. 1899-1918, 2009.

SILVA, J. C. et al. Análise de distribuição de chuva para Santa Maria, RS. Revista Brasileira de Engenharia Agrícola e Ambiental, Campina Grande, v. 11, n.1, p. 67-72, 2007.

SORATTO, R. P. et al. Leaf application of silicic acid to white oat and wheat. Revista Brasileira de Ciência do Solo, Viçosa, v. 36, n.5, p. 1538-1544, 2012.

SLEEPER, D. A.; POEHLMAN, J. M. Breeding field crops. Ames: Blackwell Pub Iowa, 2006. 424 p.
TAHIR, A. M. et al. Beneficial effects of silicon in wheat (Triticum aestivum L.) under salinity stress. Pakistan Journal of Botany, Karachi, v. 38, n. 1, p. 1715-1722, 2006.

TAKAHASHI, E.; MIYAKE, Y. Silica and plant growth. In: Proc. Intern. Seminar on Soil Environment and Fertility Management in Intensive Agriculture. Tokio: Nippon DojohiyoGakkai, 1977. p. 603-611.

VALÉRIO, I. P. et al. Seeding density in wheat genotypes as a function of tillering potential. Scientia Agricola, Piracicaba, v. 66, n. 1, p. 28-39, 2009.

VALÉRIO, I. P. et al. Seeding density in wheat: the more, the merrier? Scientia Agricola, Piracicaba, v. 70, n. 3, p. 176-184, 2013.

WANG, H.; LI, C.; LIANG, Y. Agricultural utilization of silicon in China. Studies in Plant Science, Amsterdam, v. 8, n. 1, p. 343-358, 2001.

ZAGONEL, J. et al. Doses de nitrogênio e densidades de plantas com e sem um regulador de crescimento afetando o trigo, cultivar OR-1. Ciência Rural, Santa Maria, v. 32, n. 1, p. 25-29, 2002. 